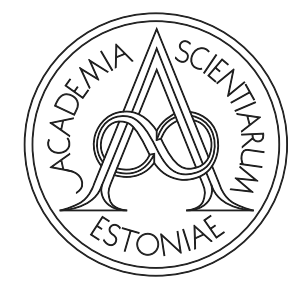

Proceedings of the Estonian Academy of Sciences,

$2021,70,4,524-532$

https://doi.org/10.3176/proc.2021.4.21

Available online at www.eap.ee/proceedings

\title{
Performance of $\mathrm{Al}_{2} \mathrm{O}_{3}-\mathrm{cBN}$ materials and the perspective of using hyperspectral imaging during cutting tests
}

\author{
Maksim Antonov ${ }^{\mathrm{a}^{*}}$, Ali Zahavi ${ }^{\mathrm{a}}$, Rahul Kumar ${ }^{\mathrm{a}}$, Mart Tamre ${ }^{\mathrm{a}}$ and Piotr Klimczyk ${ }^{\mathrm{b}}$ \\ a Tallinn University of Technology, Estonia \\ ${ }^{\mathrm{b}}$ Krakowski Instytut Technologiczny, Poland
}

Received 19 July 2021, accepted 30 July 2021, available online 11 November 2021

(C) 2021 Authors. This is an Open Access article distributed under the terms and conditions of the Creative Commons AttributionNonCommercial 4.0 International License (http://creativecommons.org/licenses/by-nc/4.0/).

\begin{abstract}
The performance of cutting tool materials (CTMs) influences the quality and lifetime of the parts produced using these tools. Unexpected fracturing or other failures of the tools lead to defects of the parts, which accelerates material fatigue and fracture processes. For the purpose of Industry 4.0 and future generations of factories, it is important to enable in-situ monitoring of cutting processes while hyperspectral imaging can serve as a powerful tool. Cubic boron nitride $(\mathrm{cBN})$ has extreme hardness and can provide improved wear resistance if mixed with other CTMs. Moreover, such materials can be used without cutting fluids, which helps to mitigate health risks in the workplace. The aim of the current work was to understand how well the current hyperspectral imaging technologies can track the changes in the performance of CTMs with the addition of cBN. This paper presents the results of multiple in-situ (obtained during cutting with a real lathe) and static (before or after cutting) tests performed with hyperspectral camera. The wear rate of CTMs and the roughness of workpieces were measured with the help of a scanning electron microscope and a 3D optical profiler respectively. The effect of cBN content and the effect of TiN or $\mathrm{ZrO}_{2}$ additives on the performance of alumina-based CTMs produced by spark plasma sintering technique is presented.
\end{abstract}

Key words: wear resistance, hyperspectral imaging, cubic boron nitride, cutting test, Industry 4.0, automation.

\section{INTRODUCTION}

Despite the fact that 3D printing (additive manufacturing) is gaining popularity nowadays, the cutting of materials (subtractive manufacturing) is still the prevailing method for production of components [1]. Usually, cutting fluids are used to reduce the friction and cool down the cutting tools. However, these fluids can cause significant health risks and illnesses such as different types of contact dermatitis, occupational acne, tracheitis, esophagitis, bronchitis, asthma, allergy hypersensitivity pneumonitis and worsening of pre-existing respiratory problems $[1,2]$. New types of cutting tools have to be developed to reduce such risks.

Cubic boron nitride (cBN) has extreme hardness and can provide improved wear resistance if mixed with other

\footnotetext{
${ }^{*}$ Corresponding author, Maksim.Antonov@taltech.ee
}

cutting tool materials (CTMs). It is one of the hardest materials and is thermally more stable than tungsten carbide or diamond $[3,4]$. The previous studies by P. Klimczyk et al. [4-6] demonstrated that it is possible to sinter composites with up to $30 \mathrm{vol} \%$ of $\mathrm{cBN}$ with alumina matrix (binder) with the help of spark plasma sintering (SPS) equipment. The reason is that with such low concentration of reinforcement the consolidation can be performed with lower pressure (usually not higher than $0.5 \mathrm{GPa}$ ) and temperature than usually required for materials with high content of reinforcement [7]. The SPS technology provides significant reduction in cost with respect to the high-pressure and high-temperature devices.

Degradation of cutting tools should be avoided since it can lead to the defects of produced parts and result in reduced service life and/or unexpected failures [8]. That is why any improvement in the monitoring of the tool's 
and workpiece's performance (especially in-situ) is of high importance, from the point of view of Industry 4.0 and next generations of production factories.

Hyperspectral imaging (HSI) is known for processing the information over the electromagnetic spectrum to identify various materials by obtaining the spectrum of each pixel of the image $[9,10]$. In other words, HSI combines the power of spectroscopy and digital image processing to identify the materials in a scene. While HSI is a fast-growing area in the remote sensing field for earth observation, emerging mobile hyperspectral cameras have made it possible to use them for material classification and object recognition in the real-world scale [11].

\section{MATERIALS AND METHODS}

\subsection{Materials}

Five alumina-based cutting tool materials reinforced by cubic boron nitride without or with $\mathrm{TiN}$ or $\mathrm{ZrO}_{2}$ additives were produced by spark plasma sintering technique - see Table 1. Their physical and mechanical properties were measured in the previous work of P. Klimczyk et al. [6]. The workpiece material was hot-rolled normalized unalloyed medium carbon (main constituents: $0.45 \% \mathrm{C}$, $0.2 \% \mathrm{Si}, 0.7 \% \mathrm{Mn}$, base $-\mathrm{Fe}$ ) steel $\mathrm{C} 45$ according to EN 10083-2.

\subsection{Wear rate and roughness measurements}

The cutting tests were performed on Sumore SP2138 lathe operated with computer numerical control (CNC). The test samples produced by SPS were cut into the required shape and then the edges were ground by diamond disc with cooling (Fig. 1A). The total number of cuts with a depth of $0.075 \mathrm{~mm}$ and a width of $80 \mathrm{~mm}$ was 70 ; feed rate was $0.05 \mathrm{~mm}$ per rotation $\left(0.88 \mathrm{~mm} \mathrm{~s}^{-1}\right)$; average cutting speed was $100 \mathrm{~m} \mathrm{~min}^{-1}\left(1.67 \mathrm{~m} \mathrm{~s}^{-1}\right)$; total duration of cutting was $105.66 \mathrm{~min}(6342 \mathrm{~s})$; total length of the removed chip was $10566 \mathrm{~m}$, Fig. 1B. The linear and volumetric wear rates were measured according to scanning electron microscope (Hitachi TM1000, SEM) images. The SEM images of the worn cutting tools from three sides with at least three magnifications were imported into AutoCAD 2020 software and analysed. Volumetric wear was approximated by triangular pyramids, Fig. 1C. Roughness and 3D topography were measured with the help of Bruker ContourGT-K0+ optical 3D profiler.

\subsection{Hyperspectral investigations during and after the cutting test}

The system was comprised mainly of a hyperspectral camera, a light source, the test sample fixed in the lathe, and a frame for fixation of components (Fig. 2). The mobile hyperspectral camera used for conducting these experiments was SPECIM IQ (Spectral Imaging Ltd., Finland), a VNIR (visible-near-infrared) camera which collects the spectrum of each pixel of the image in the range of 400-1000 nm; number of the bands was 204; spectral resolution was $7 \mathrm{~nm}$; spatial sampling was 512 pix; acquisition mode was Pushbroom (line-scan imaging) [12]. The recording of one image took approximately 5 minutes. Similar to other computer vision applications, the light source used during the image acquisition phase plays a vital role in the validity of the results. Incandescent lights were applied as the best illumination source for indoor hyperspectral imaging applications [13]. A frame was assembled to install the incandescent light in an appropriate height above the field of view (FOV).

The spectrum of the insert material (before testing) and steel workpiece (after testing) was extracted in static conditions (without movement), while additionally images of the cutting zone were taken in-situ during machining to study the effect of feed rate $(2.5,5.0 \mathrm{~mm} / \mathrm{s})$, rotational speed of the workpiece $(500,1000 \mathrm{rpm} / 8.33$, $16.66 \mathrm{rps})$ and depth of cutting $(0.1,0.2 \mathrm{~mm})$.

For acquiring the suitable images for analysis, more than 50 images from the scene from different angles with different scenarios were taken. These images were taken to find the best distance from the illumination source to

Table 1. Properties of the cutting tool materials investigated [6]

\begin{tabular}{|c|c|c|c|c|c|}
\hline Designation & Composition, $\%$ & $\begin{array}{c}\text { Relative } \\
\text { density, \% }\end{array}$ & $\begin{array}{c}\text { Young's } \\
\text { modulus, GPa }\end{array}$ & $\begin{array}{l}\text { Vickers hardness } \\
\text { HV30, GPa }\end{array}$ & $\begin{array}{l}\text { Fracture toughness, } \mathrm{K}_{\mathrm{IC}} \\
\text { (indentation method), } \\
\mathrm{MPa} \cdot \mathrm{m}^{1 / 2}\end{array}$ \\
\hline A100 & $\mathrm{Al}_{2} \mathrm{O}_{3}$ & $>99$ & $398 \pm 7$ & $16.3 \pm 0.9$ & $3.9 \pm 0.6$ \\
\hline A10B & $\mathrm{Al}_{2} \mathrm{O}_{3}-10 \mathrm{cBN}$ & 98 & $421 \pm 9$ & $16.4 \pm 0.5$ & $5.4 \pm 0.5$ \\
\hline $\mathrm{A} 20 \mathrm{~B}$ & $\mathrm{Al}_{2} \mathrm{O}_{3}-20 \mathrm{cBN}$ & 96 & $442 \pm 8$ & $18.7 \pm 0.3$ & $5.8 \pm 0.4$ \\
\hline $\mathrm{A} 20 \mathrm{~B} 10 \mathrm{~T}$ & $\mathrm{Al}_{2} \mathrm{O}_{3}-20 \mathrm{cBN}-10 \mathrm{TiN}$ & 96 & $428 \pm 11$ & $17.2 \pm 0.3$ & $5.5 \pm 0.5$ \\
\hline A20B15Z & $\mathrm{Al}_{2} \mathrm{O}_{3}-20 \mathrm{cBN}-15 \mathrm{ZrO}_{2}$ & 99 & $409 \pm 13$ & $18.8 \pm 0.7$ & $5.4 \pm 0.5$ \\
\hline
\end{tabular}




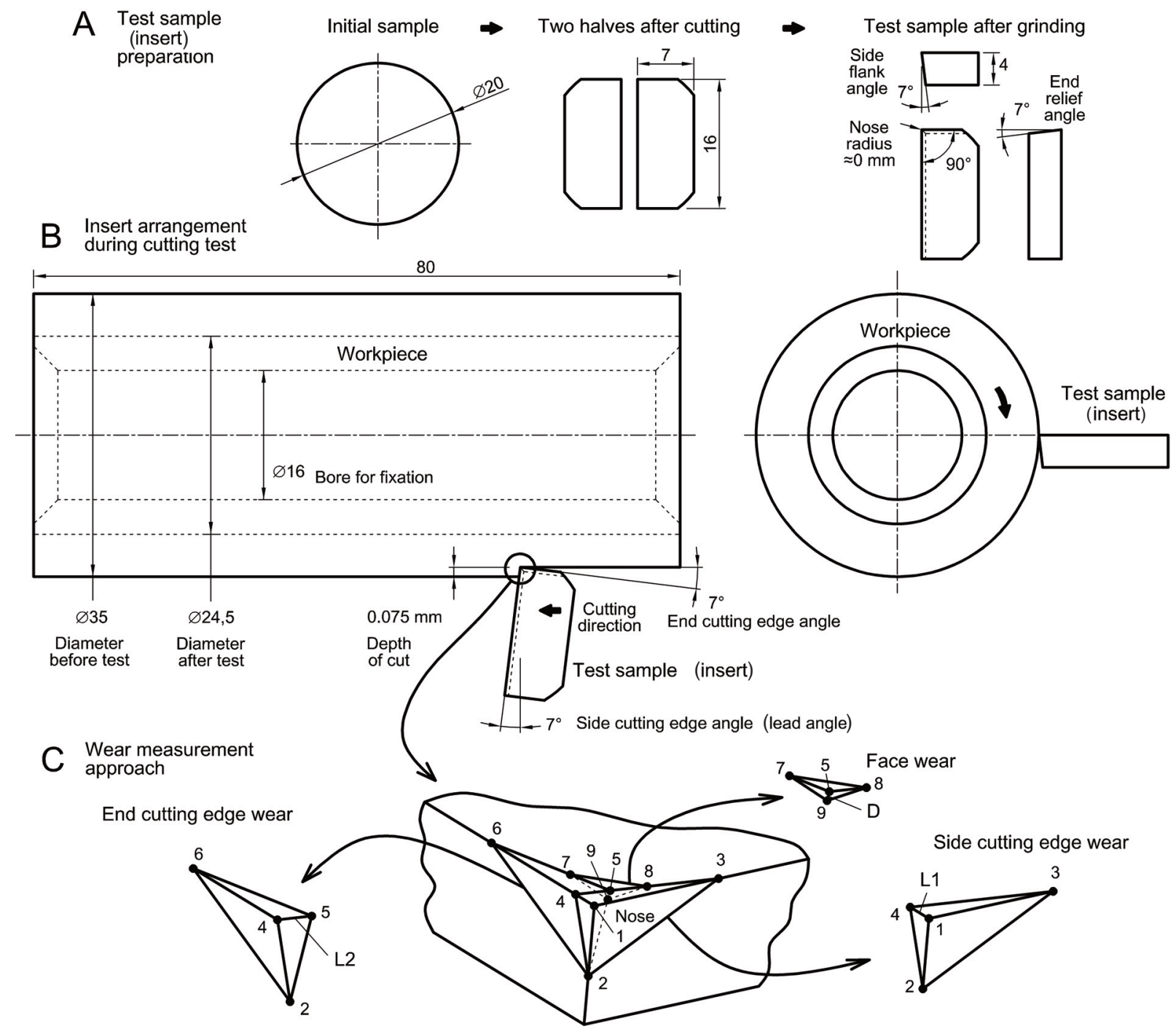

Fig. 1. The sample (insert) preparation (A), its arrangement during the cutting test (B) and the wear rate measurement approach (C).

the material, and from the material to the camera, as well as the proper angle and the proper field of view. After that the images were examined one by one and fewer than ten images were selected. Also, the best positions of the illumination source, camera and material were established. Therefore, after these experiments by finding the optimum values of these parameters, further experiments were performed in this optimum situation.

\section{EXPERIMENTAL RESULTS}

\subsection{Wear rate measurements}

The wear rates of CTMs are presented in Fig. 4 along with the roughness of workpieces after 70 cuts. The volumetric wear rates are more reliable indications, though both types of approaches provided similar results.
It is possible to see that wear resistance of alumina during dry cutting can be significantly (up to 3 times according to volumetric wear) improved by the addition of $20 \%$ of $\mathrm{cBN}$ and $15 \%$ of $\mathrm{ZrO}_{2}$ while providing the same roughness for the produced parts. According to SEM images (Fig. 5A), pure alumina (A100) was suffering from chipping of the cutting edge. Reduced performance of the materials with $10 \%$ and $20 \%$ of cBN could be explained by the loss of alumina between grains, which facilitates the adhesion of steel workpiece material onto the cutting insert and its overheating.

\subsection{Hyperspectral investigations during and after the cutting test}

For minimizing the error that might happen during the image acquisition phase, each cutting tool material was under the experiment five times, and the spectral signa- 


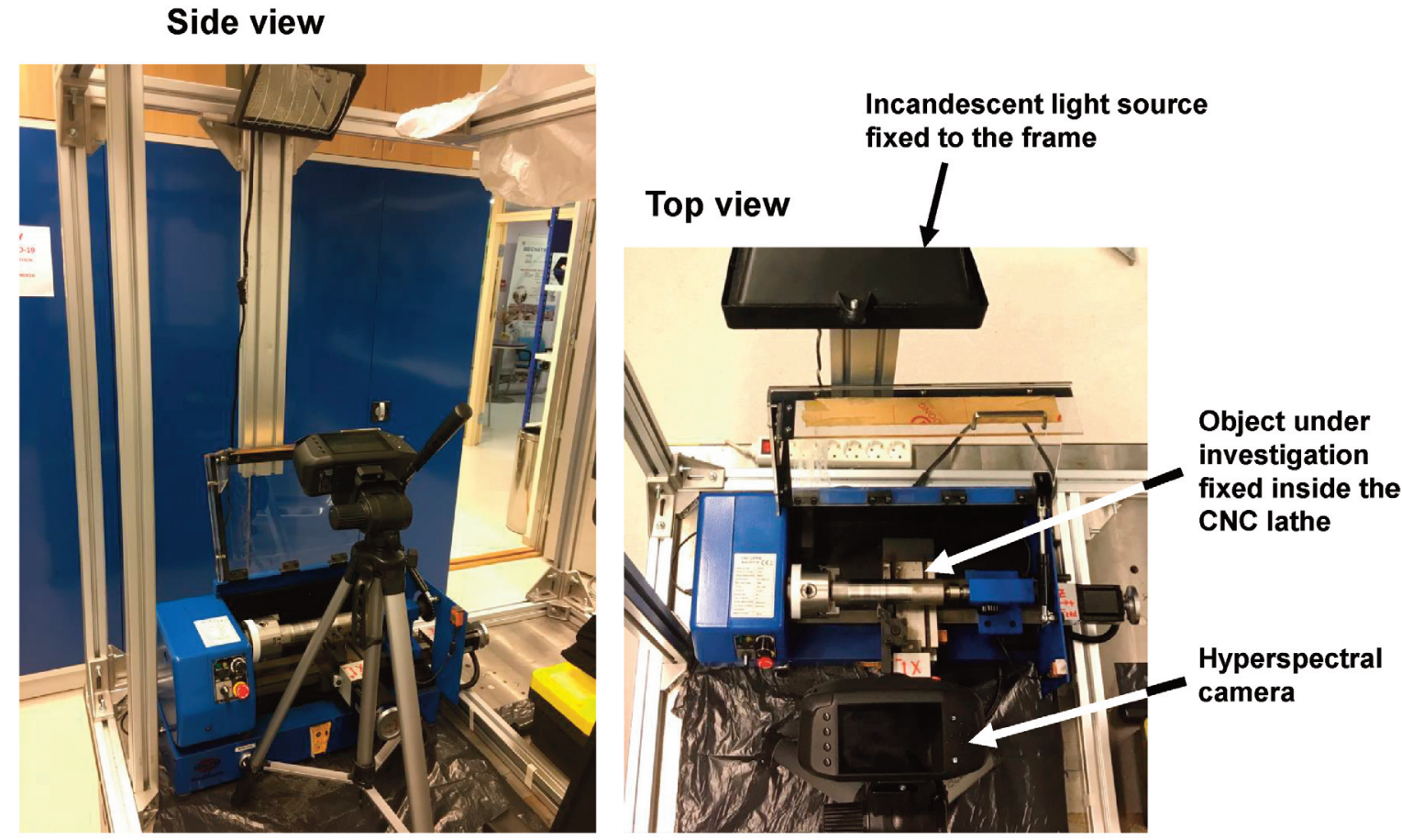

Fig. 2. Test setup for hyperspectral investigation during the cutting test (side and top views).

tures of ten different pixels of the material were conducted. Then, the average of these 50 spectra $(5$ multiplied by 10) was calculated to have a final spectrum of the material which may better represent the object or the material. Moreover, since the spectral signature extracted from the hyperspectral image has small fluctuation (less than one percent) over the electromagnetic spectrum, for smoothing the graph in the pre-processing stage, Savitzky-

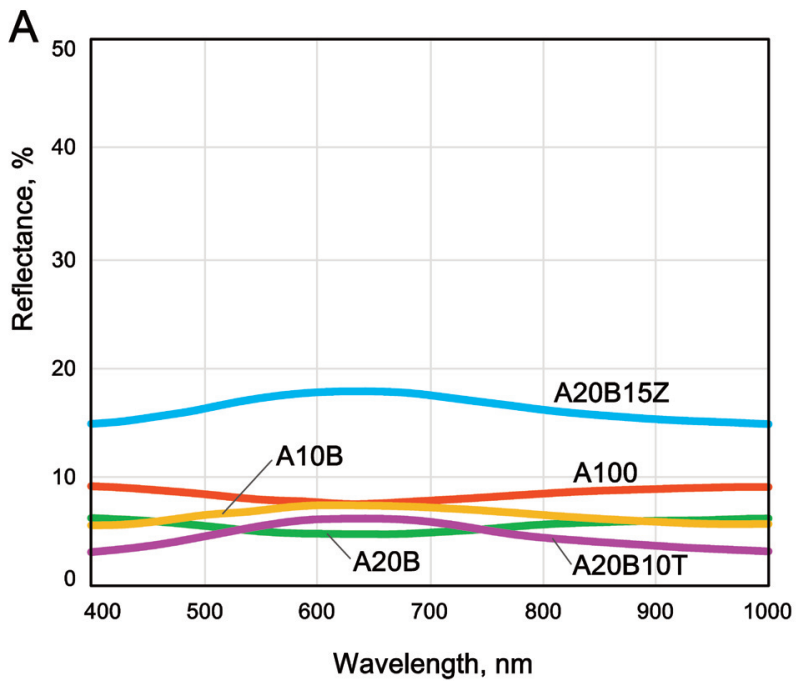

Golay filter was used similarly to SPECIM IQ Studio software (for processing the hyperspectral images acquired by SPECIM IQ camera) [14]. The graphs show the spectral signature of the cutting tool materials (Fig. 3A), and the spectral signature of the steel workpiece after being cut by these tools (Fig. 3B).

It can be interpreted from Fig. 3A that the A20B15Z material (blue line) has a brighter colour than other

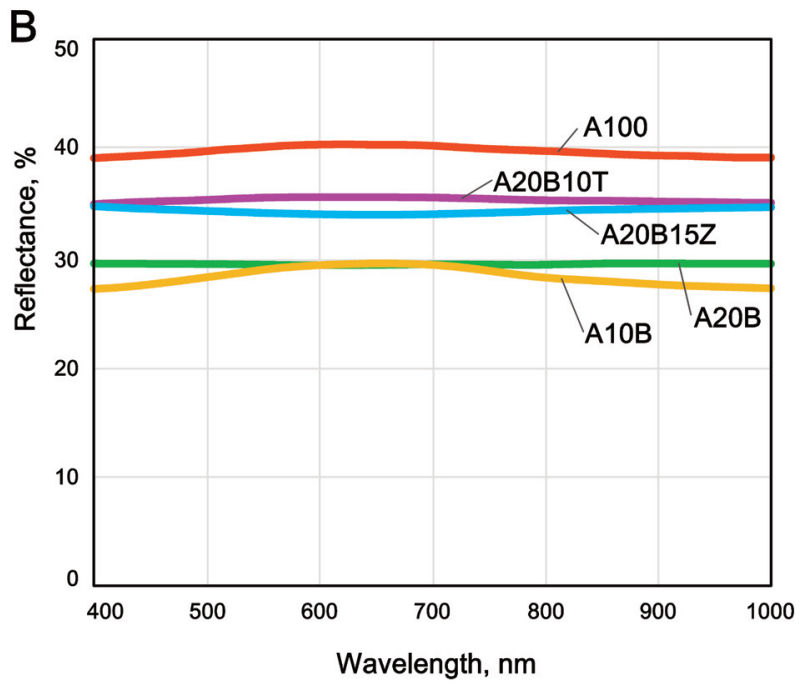

Fig. 3. Spectral signature of the cutting tool materials (A) and spectral signature of the steel workpiece taken after the cutting test (B) in the range of $400-1000 \mathrm{~nm}$. 

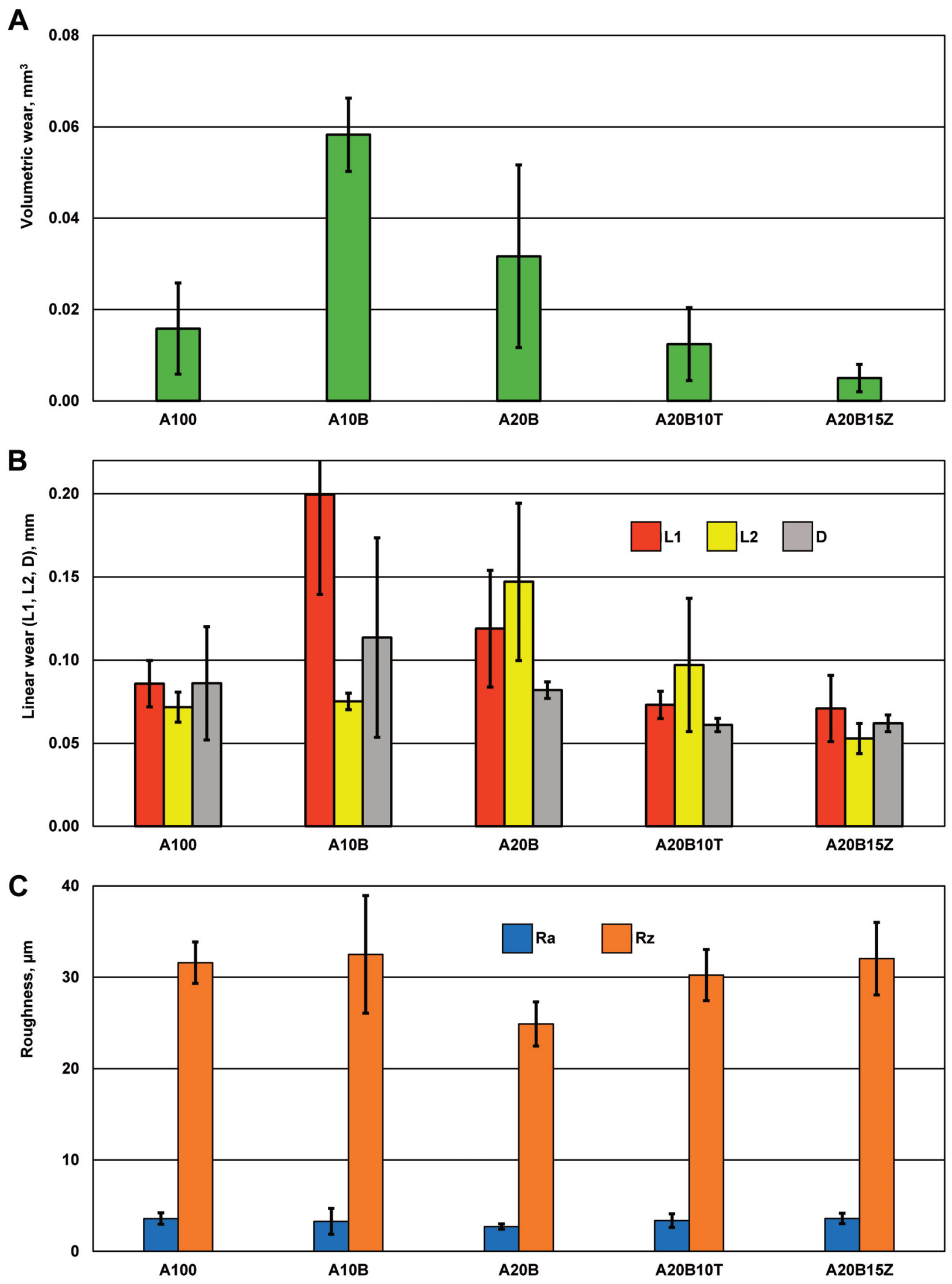

Fig. 4. The volumetric (A) and linear (B) wear rates of tested samples; roughness of the workpiece after the cutting test (C). 

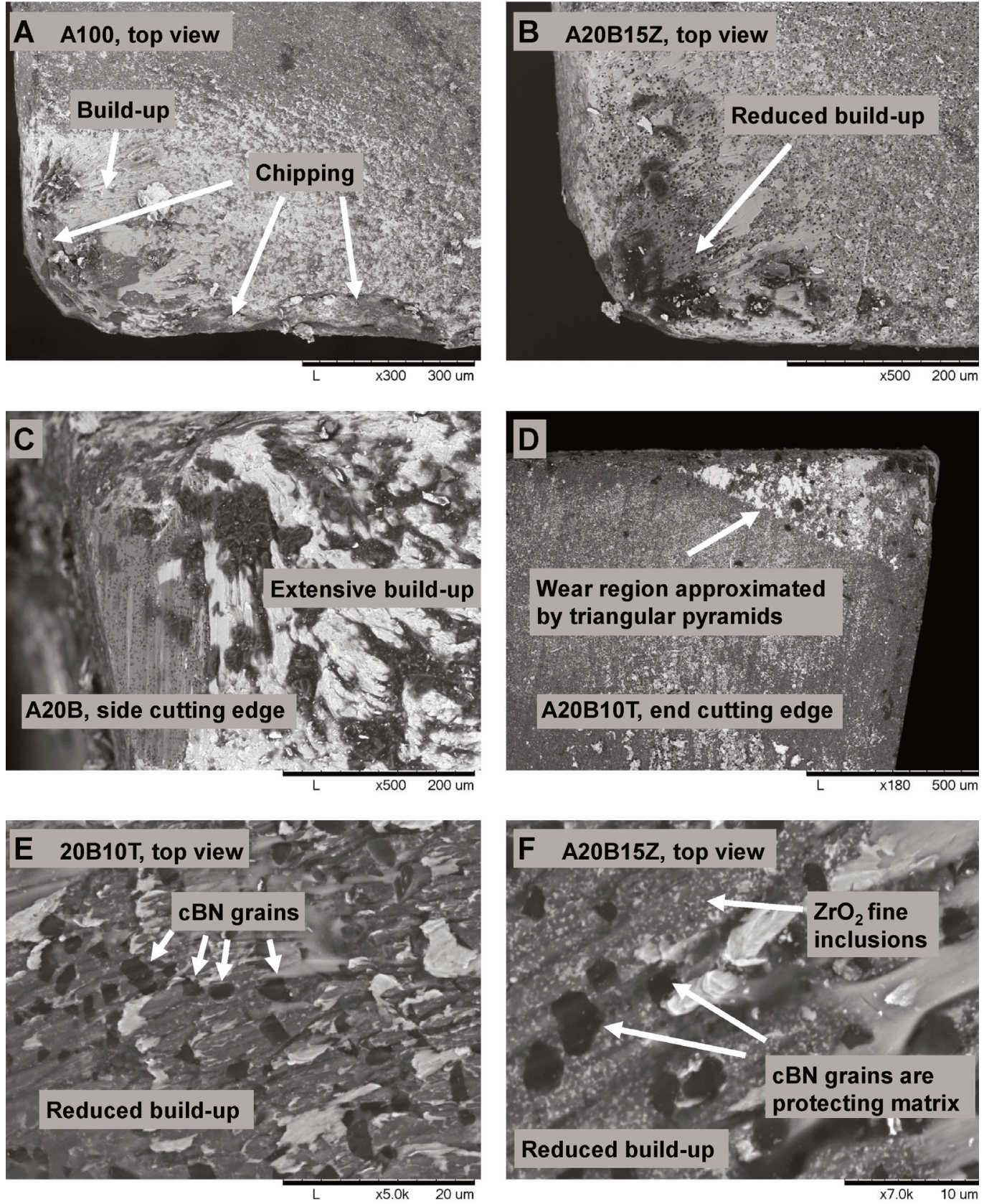

Fig. 5. Scanning electron microscope (SEM) images of the cutting tools' worn surfaces. Please take the magnification into account in the comparison of images.

materials, and it reflects more energy into the camera. Therefore, its spectral signature has a higher percentage of reflectance in comparison with other materials across the spectrum.

However, for identifying the materials presented in Fig. 3A, one has to observe significant peaks or depths, while in these experiments the spectral signatures of all materials were almost flat (less than a three-percent change across the range). In other words, it was not possible to see any significant peaks or depths related to these materials (the characteristic peaks) in the VNIR range. Furthermore, in Fig. 3B, taken by VNIR camera, the spectrum of the workpiece is almost flat across the entire range in all experiments. It shows that the characteristic peaks of steel are outside the VNIR range.

Spectral signatures taken during in-situ testing have shown that doubling of the value of feed rate, rotational speed of the workpiece and the depth of cutting resulted in $\max 0.1 \%, 1.0 \%$ and $1.0 \%$ change of the workpiece reflectance respectively. Using of a near-infrared camera 
(1000-1700 nm) might lead to more precise identification of materials and control of the cutting process.

\section{DISCUSSION}

As it was indicated earlier, the volumetric and linear wear rates provided similar results. The authors advise using the volumetric method as more precise since it considers more data. For example, when the wear of end cutting edge was calculated, then in addition to L2, also the distances "4-2" and "6-4" were taken into account (Figs 1 and 5D). On the other hand, determination of the volu- metric wear rates is more time consuming due to the necessity to collect more SEM images (than required for linear measurements) and the additional time to analyse the collection of images in AutoCAD 2020 software. If required, the metallic (transferred from workpiece) material build-up can be removed by etching due to the fact that the cutting tool is ceramic.

The reference material (pure alumina, A100) has a sufficiently low wear rate and provides low roughness for the workpiece after the completion of the cutting test (Fig. 4). However, the value of wear rate or roughness alone is not sufficient to make a final judgement. The 3D images of the workpiece are presented in Fig. 6 where it
A Cutting by A100, image size $1700 \times 1280 \mu \mathrm{m}$

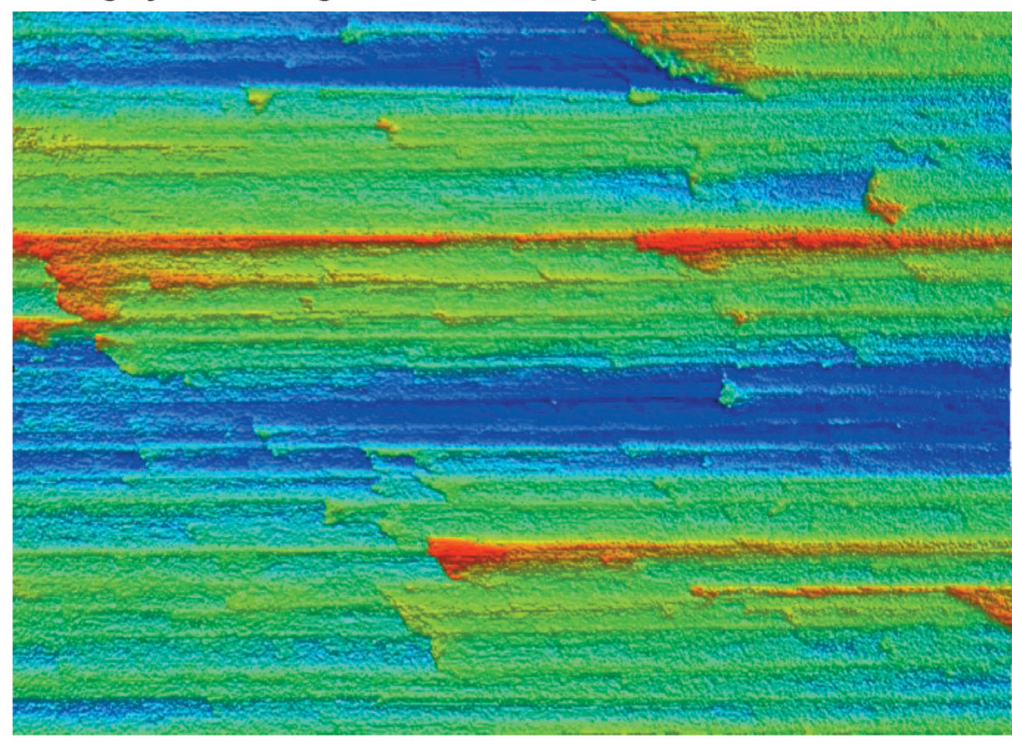

B Cutting by A20B, image size $1700 \times 1280 \mu \mathrm{m}$

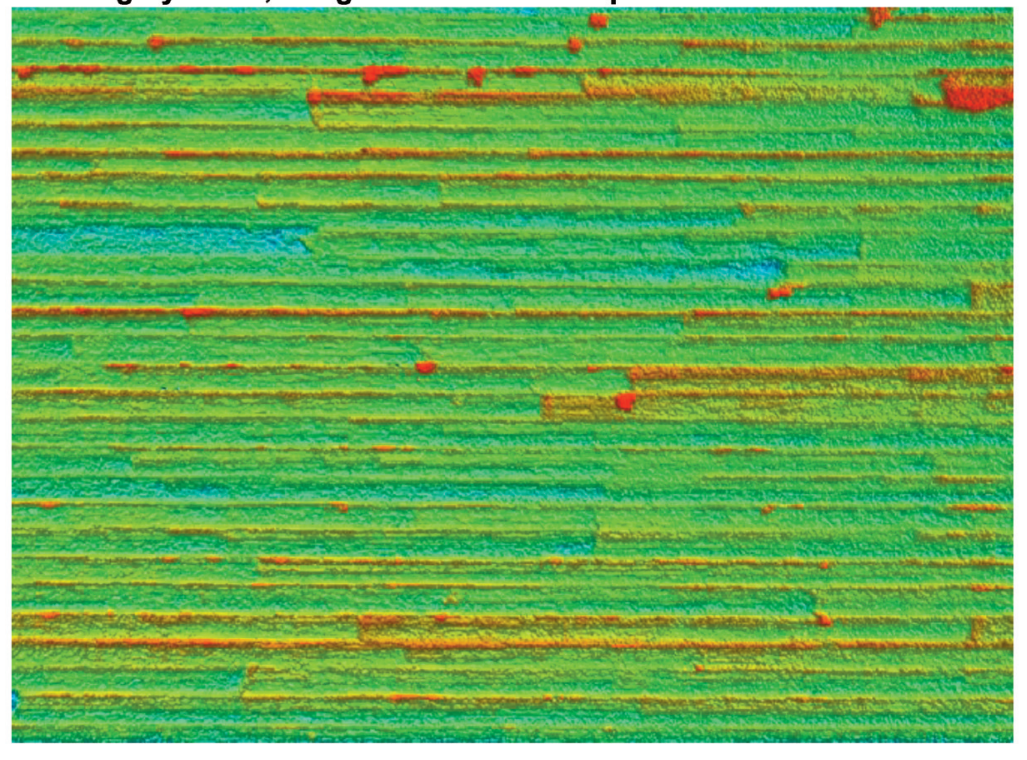

$\mu \mathrm{m}$

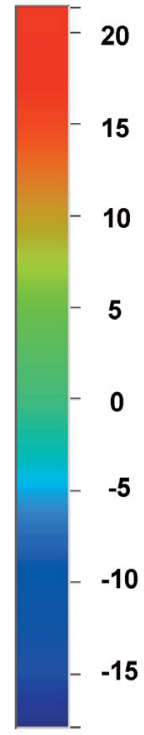

$\mu \mathrm{m}$

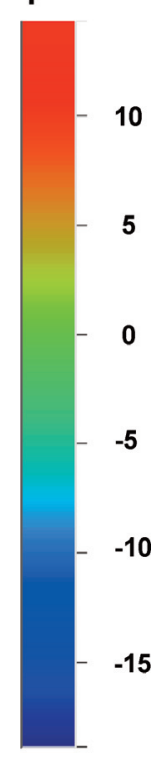

Fig. 6. 3D exemplary images of the workpiece surface after the cutting test by A100 and A20B. 
is clearly visible that the surface after cutting with the A100 material is irregular, and in many places, the cuts are overlapping. The latter is an indication of the dulling of the cutting tool, formation of the build-up and resultant overheating of the workpiece and tool. Extreme local overheating of the tool is critical for ceramic materials and can lead to cracking. The chipping of the A100 cutting tool is indicated in Fig. 5A.

The nose (tip) radius of the cutting tool is usually provided to enable longer life [15]. The tools used in the current work were without radius to make it possible to reduce consumption (waste) of the workpiece material (to reduce depth of cut and feed). We assume that the tool material that works well in such harsh conditions will show good performance with rounded nose as well. It is important to mention that there was a self-organization process during tribological testing that actually led to a more suitable shape of nose - see Fig. 5A and B. The final shape of nose was close to rounded and the radius was about $100 \mu \mathrm{m}$.

The same materials were tested by two laboratory test methods (another work that is currently in the publishing process) - reciprocative and surface fatigue. The A20B15Z material had a significantly lower wear rate than the reference A100 material only in the surface fatigue test. This was explained by the fact that the removal of cBN grains by fatigue mechanism was intensified during the reciprocative (direction of friction force is changing) test. This can lead to the possible conclusion that the laboratory surface fatigue test (ball hitting the surface of the test sample) is suitable for the prediction of performance in cutting conditions. However, during the surface fatigue test, the A20B10T material had at least two times higher wear than A20B, which does not correspond to the results of the current cutting tests. The better relative performance of A20B10T during the cutting test could be explained by the fact that TiN, when added into cutting tools based on $\mathrm{WC}-\mathrm{Co}$, contributes to the reduction of build-up (compare Fig. 5C and $\mathrm{E}$ ), which is favourable for the reduction of friction, temperature in the cutting zone, thermal shocks, cracking, etc. Thus, a careful selection of laboratory test methods mimicking real conditions is required.

The analysis of SEM images of the cutting inserts allows to draw the conclusion that the formation of buildup, removal of alumina matrix between $\mathrm{cBN}$ grains, removal of unsupported cBN grains are the main steps of wear of the studied composites. It was detected that these processes are continuous but ongoing in a cyclic manner. The removal of matrix takes some time, then the removed matrix provides better conditions for build-up while a well-developed build-up leads to higher frictional heating of the surface, which will result in thermal damage (microcracks were detected in the alumina matrix) and the removal of build-up and some of $\mathrm{cBN}$ grains. Then, the cycle is repeated.

The currently available and applied hyperspectral camera is highly sophisticated, it requires careful handling. One measurement takes approximately 5 minutes and the obtained results require comprehensive analysis. It should be mentioned that another available hyperspectral camera used during the first stages of the research lost the precision of measurement due to minor mechanical shocks even with proper handling. There is great hope that future generations of hyperspectral cameras will be more oriented to industrial cutting applications, and will be more robust. Currently, there is a great boom in using hyperspectral imaging in different areas such as agriculture, forestry, oceanography, medicine, geology, security, archaeology, recycling, but special cameras for cutting applications are not yet available $[16,17]$. It is expected that future generations suitable for Industry 4.0 factories will have a wider spectrum, be faster and will be able to monitor not only the workpiece material (sufficiently large area) but also the nose (tip) of a cutting insert and be able to work in fully automatic regime.

\section{CONCLUSIONS}

- It was detected that the wear resistance of alumina during dry cutting can be significantly (up to 3 times according to volumetric wear) improved by the addition of $20 \%$ of $\mathrm{cBN}$ and $15 \%$ of $\mathrm{ZrO}_{2}$ while providing the same roughness for the produced parts. Such material can be used without cooling liquids to mitigate occupational health risks.

- It was detected that unreinforced reference pure alumina exhibits chipping of the cutting edge, which can lead to defects of the parts, contributing to their fatigue and fracture processes.

- It was possible to establish in-situ monitoring of the cutting process by hyperspectral camera.

- Spectral signatures taken during in-situ testing show that doubling of the value of feed rate, rotational speed of the workpiece and depth of cutting resulted in max $0.1 \%, 1.0 \%$ and $1.0 \%$ change of the workpiece reflectance respectively, which was not sufficient for tracking the tool performance. It is advisable to use a near-infrared camera (1000-1700 nm) to achieve more precise identification.

\section{ACKNOWLEDGEMENTS}

The authors would like to acknowledge the support from the Estonian Ministry of Education and Research (M-ERA.NET DURACER ETAG18012, PRG643). The publication costs 
of this article were covered by the Estonian Academy of Sciences and Tallinn University of Technology.

\section{REFERENCES}

1. Shaw, M. C. Metal Cutting Principles. 2nd ed. Oxford University Press, New York, NY, 2005.

2. Cutting fluid. https://en.wikipedia.org/wiki/Cutting_fluid (accessed 2021-05-05).

3. Waqar, T., Akhtar, S. S., Arif, A. F. M. and Hakeem, A. S. Design and development of ceramic-based composites with tailored properties for cutting tool inserts. Ceram. Int., 2018, 44(18), 22421-22431. https://doi.org/10.1016/j.ceramint. 2018.09.009

4. Klimczyk, P., Figiel, P., Petrusha, I. and Olszyna, A. Cubic boron nitride based composites for cutting applications. $J$. Achiev. Mater. Manuf. Eng., 2011, 44(2), 198-204.

5. Klimczyk, P., Cura, M. E., Vlaicu, A. M., Mercioniu, I., Wyżga, P., Jaworska, L. and Hannula, S.-P. $\mathrm{Al}_{2} \mathrm{O}_{3}-\mathrm{cBN}$ composites sintered by SPS and HPHT methods. J. Eur. Ceram. Soc., 2016, 36(7), 1783-1789. https://doi.org/10.1016/ j.jeurceramsoc.2016.01.027

6. Klimczyk, P., Wyżga, P., Cyboroń, J., Laszkiewicz-Łukasik, J., Podsiadło, M., Cygan, S. and Jaworska, L. Phase stability and mechanical properties of $\mathrm{Al}_{2} \mathrm{O}_{3}-\mathrm{cBN}$ composites prepared via spark plasma sintering. Diam. Relat. Mater., 2020, 104, 107762. https://doi.org/10.1016/j.diamond.2020. 107762

7. Kumar, R., Antonov, M., Beste, U. and Goljandin, D. Assessment of 3D printed steels and composites intended for wear applications in abrasive, dry or slurry erosive conditions. Int. J. Refract. Met. Hard Mater., 2020, 86, 105126. https://doi.org/10.1016/j.ijrmhm.2019.105126
8. Meinhard, D., Haeger, A. and Knoblauch, V. Drilling induced defects on carbon fiber-reinforced thermoplastic polyamide and their effect on mechanical properties. Compos. Struct., 2021, 256, 113138. https://doi.org/10.1016/ j.compstruct.2020.113138

9. Chang, C. Hyperspectral Imaging: Techniques for Spectral Detection and Classification. Springer Science \& Business Media, Berlin, Heidelberg, 2003.

10. Grahn, H. F. and Geladi, P. Techniques and Applications of Hyperspectral Image Analysis. John Wiley \& Sons, Chichester, 2007.

11. Zahavi, A. Deep learning for material and object identification using hyperspectral imaging. Master's thesis. Tallinn University of Technology, Estonia, 2020.

12. Specim IQ Technical Specifications. https://www.specim.fi/ iq/tech-specs (accessed 2021-05-05).

13. Zahavi, A., Palshin, A., Liyanage, D. C. and Tamre, M. Influence of illumination sources on hyperspectral imaging. In Proceedings of the 2019 20th International Conference on Research and Education in Mechatronics (REM), Wels, Austria, May 23-24, 2019. IEEE, 1-5. https://doi/10.1109/ REM.2019.8744086

14. Specim IQ Studio. Software for Specim IQ camera. https:// www.specim.fi/iq/specim-iq-studio (accessed 2021-05-05).

15. Hard part turning with CBN, C-2940:137 ENG/01. AB Sandvik Coromant, 2012. https://www.sandvik.coromant.com/ sitecollectiondocuments/downloads/global/catalogues/en-gb/c2940-137.pdf (accessed 2021-05-05).

16. Cubert Science Activity Report 2020. https://cubert-gmbh. com/cubert-science-activity-report-2020 (accessed 2021-0505).

17. Use Cases \& Application Notes. https://www.hyspex.com/usecases-application-notes (accessed 2021-05-05).

\title{
$\mathrm{Al}_{2} \mathrm{O}_{3}-\mathrm{cBN}$ materjalide käitumise uurimine lõikamiskatsete ajal ja hüperspektraalse pildistamise testimine lõikeprotsessi jälgimisel
}

\author{
Maksim Antonov, Ali Zahavi, Rahul Kumar, Mart Tamre ja Piotr Klimczyk
}

Lõikeriistade materjalide (LRM) käitumine mõjutab nende abil valmistatud toodete kvaliteeti ja eluiga. Tööriistade ootamatu purunemine või teised tõrked toovad kaasa toodete defekte, mis kiirendavad materjalide väsimist ja purunemisprotsesse. Industry 4.0 ja tuleviku tehaste jaoks on oluline, et oleks võimalik kohapeal jälgida lõikeprotsesside kulgu, kus hüperspektraal-pilditehnika võiks olla võimas tööriist. Kuubiline boornitriid (cBN) on äärmiselt kõva ja võib teiste LRM-dega segatuna tagada parema kulumiskindluse. Lisaks eelnevale saab selliseid materjale kasutada lõiketöötluseks ilma jahutusvedelikuta, mis aitab vähendada terviseriske töökohal. Käesoleva töö eesmärk oli aru saada, kui hästi suudavad praegused hüperspektraal-pilditehnikad jälgida LRM-de käitumise muutusi cBN-i lisamise puhul. Selles artiklis esitatakse tulemusi, mis on saadud reaalse treipingiga treimisel VNIR hüperspektraalkaameraga tehtud staatiliste piltide (vahetult enne või pärast lõikamist) analüüsil. LRM-de kulumiskiirus ja toorikute lõppkaredus mõõdeti vastavalt skaneeriva elektronmikroskoobiga ja 3D-optilise profilomeetriga. On näidatud $\mathrm{cBN}$ sisalduse ja TiN või $\mathrm{ZrO}_{2}$ lisandite mõju sädeplasma paagutamise meetodil valmistatud alumiiniumoksiidi sideainega LRM käitumisele. 